\title{
Transformation, Job Creation and Subsidies to Creative Industries: The Case of South Africa's Film and Television Sector
}

\author{
Alan Collins (CORRESPONDING AUTHOR) \\ Hobart Houghton Research Fellow \\ Department of Economics and Economic History \\ Rhodes University \\ PO Box 94 \\ Grahamstown 6140, South Africa \\ and \\ Economics and Finance Group \\ Portsmouth Business School \\ University of Portsmouth \\ Portsmouth, PO1 3DE, UK \\ Email: alan.collins@port.ac.uk \\ Telephone: +442392844128 \\ Fax: +442392 844037

\section{Jen Snowball} \\ Department of Economics and Economic History \\ Rhodes University \\ PO Box 94 \\ Grahamstown 6140 \\ South Africa \\ Email: j.snowball@ru.ac.za \\ Telephone: +27466037405 \\ Fax: +27 466225120
}

Acknowledgement: The financial support of Economic Research Southern Africa is gratefully acknowledged. 


\title{
Transformation, Job Creation and Subsidies to Creative Industries:
}

\author{
The Case of South Africa's Film and Television Sector
}

\begin{abstract}
Many governments have tried to stimulate economic growth via policy in the creative industries. South Africa is no different but additionally has an overarching aim of achieving social and labour market 'transformation' to move away from the legacy of the apartheid era. The effectiveness of incentives provided to the film and television sector in South Africa are considered in terms of their stated objectives of job creation, skills and knowledge transfer and the attraction of foreign direct investment. Informed by empirical analysis of incentive scheme data and supplemented by elite interviews with key informants, some specific policy revisions are proposed.
\end{abstract}

Key words: South Africa, transformation, job creation, subsidy, creative industries 


\section{Transformation, Job Creation and Subsidies to Creative Industries:}

The Case of South Africa's Film and Television Sector

\section{INTRODUCTION}

South African society and its economy still remain fractured in terms of income inequality that divides, in large part, along lines of race and ethnicity (World Bank Country Report 2012). It does so with substantial variation in poverty rates and instances of high index scores of multiple social deprivations in some provinces and amongst black Africans in particular (Statistics South Africa 2012). These are often adjacent to areas and regions of considerably higher incomes and wealth. In a context in which there are so many competing demands on limited public funds, subsidies and tax relief to industry need to be critically examined.

In a developing country context, Cunningham et al. (2008:5) note that despite the status of the creative industries as potential new growth areas “...the output of creative industries barely figures in the reckoning of productivity" and they "... are at a competitive disadvantage due to a more pressing need for financial aid to be directed at problems of education, poverty and institution building."

South Africa has a small, but already well-established private sector creative industry, an important part of which is the film and television sector. However, especially in the highly mobile global film and television industry, competition is fierce. Industry stakeholders have argued that, in order to encourage local productions, co-productions with foreign companies and foreign productions filmed in South Africa, government support is necessary. 
The film and television sector can and does provide jobs and skill development in South Africa, building on a cluster of creative industries in the private and public sector centred on the city of Cape Town (Barnard and Tuomi 2008), which on a range of criteria (see Evans 2009) would seem to warrant the appellation of South Africa's main creative city. In addition, a report commissioned by the Department of Labour on the creative industries (Creative Industries Report, 2008) found that the economic activity generated by the film and television industry in the Western Cape was R2.5b in $2003 / 4$ as compared to only R1.3b generated by the sector in Gauteng.

Beyond developing the domestic industry, filming (and other pre- and post-production activities) by foreign companies, or combined foreign and South African productions (referred to as co-productions), can result in valuable foreign exchange inflows, technology transfer, and opportunities for the development of the skills-base of South African film makers. In this sense, the film and television industry can be understood as an opportunity to attract inward foreign direct investment (FDI) and might be expected to provide the kinds of benefits to a host economy typically associated with FDI projects in other sectors, such as manufacturing (De Mello Jnr. 2007). However, 'subsidy competition' (see, for example, Barros and Cabral 2000, Bjorvatn and Eckel 2006) among countries is observed in this sector as in many others, with a further layer of decision-making complexity presented by the volatility of exchange rate movements.

It has also been argued that the film and television sector has the potential to offer marketing benefits for South Africa in global terms, while providing cultural and educational benefits for its citizens, as well as visible evidence of a growing inclusivity in South African public life (DTI 2011; DTI 2012; NFVF 2008). 
While there have been some industry feedback reports to the South African Department of Trade and Industry (DTI) on the design and effectiveness of incentives (subsidies) to the film and television sector in South Africa (Industry Reports 2009, 2012), they have not hitherto been subject to detailed independent academic empirical scrutiny. This study reports on an analysis of recent project-level data held by the DTI to examine the effectiveness of the current incentive scheme in terms of the broader aim of transformation in South Africa and its explicitly stated objectives of (i) creating jobs, (ii) developing skills and the technological knowledge base and (iii) attracting foreign exchange.

The paper is organized in the following manner: Section 2 briefly considers past work on subsidies in the creative industries and the more limited literature that addresses the developing country context. The transformation background and context of subsidies to this sector in the South African case is then considered. The next two sections unfold the data and modes of analysis employed along with a discussion based on the study findings. A summary and some concluding remarks are then provided.

\section{AN OVERVIEW OF SUBSIDIES PROVIDED TO THE CREATIVE AND CULTURAL INDUSTRIES IN SOUTH AFRICA}

There is much international literature concerning the assessment of the case for and against subsidizing the arts and creative industries (see, for example, Fullerton, 1991, Austen-Smith, 1994, Throsby, 1994). The standard microeconomic case for the use of subsidies is as a market corrective to counteract undersupply of a good with large external benefits, or merit good features and has been further augmented in a creative industries context by various justifications. For example, on the demand side, the creative industries are argued to have important educational, cultural and audience development objectives (Cunningham 2002). 
On the supply side, subsidies are argued for on the grounds of, inter alia, infant industry status (Hindley and Smith, 1984, Mas-Colell, 1999), and labour skills development for accelerated city/regional economic development (see, for example, Hall 2000, Gwee 2009).

Films and television programmes are globally traded and much production is similarly globally footloose. Accordingly, while South Africa has considerable economic and natural advantages to such production in terms of labour cost advantages, use of English and diverse film locations that provide very accurate facsimiles for other country locations, its Government authorities and producer organizations still feel they must compete for FDI in subsidy terms (Industry Report 2012; Tuomi, 2007).

However, there are also those who argue against the case for subsidy: Tannenwald (2010), for example, assembles a wide body of evidence in the US context, to suggest that film incentive schemes are systematically over-generous to producers, costly to governments and typically feature negative rates of return. He argues that they 'crowd out' unsubsidized production that might have occurred otherwise; that they cannot provide sustainable industrial activity since 'film subsidy wars' are unwinnable and centred on very fragile, footloose production; and that the evidence base used to justify their introduction is typically deeply flawed (Tannenwald 2010).

\section{TRANSFORMATION AND THE BACKGROUND OF THE SOUTH AFRICAN FILM AND TELEVISION SUBSIDY}

\section{(a) The history and aims of subsidy to the South African film and television sector}

South Africa's film industry has a long history, starting in 1910 with the founding of African Film Productions and "The Great Kimberly Diamond Robbery" (NFVF 2000). An early 
subsidy system, introduced in 1956 , was based on tax rebates to encourage local productions for mainly white audiences under apartheid. Although the subsidy was discontinued in 1992 , South Africa still maintained a skilled technical and crew base, as well as audio-visual facilities. This acted as a base for the revitalization of the industry under the new subsidy scheme introduced in 1997, after the establishment of the National Film and Video Foundation (NFVF 2000). Other advantages offered by the South African film and television industry include a great variety of locations, generally good weather, high standards of copyright protection, and "a shrinking, but sill tangible cost advantage over developed countries" (Tuomi 2007:76).

A report on the creative industries in South Africa, commissioned by the Department of Labour (Creative Industries Report 2008), pointed out that many African countries had "recognized the potential of the cultural sector to alleviate poverty and create jobs and have committed their governments to support these sectors", including subsidy, policy and legislation (Creative Industries Report 2008:13). The Report argues that the film industry in general has a large effect on employment, skills development, tourism spin-offs and GDP growth, both directly, and through multiplier effects. Total turnover for the South African film industry for 2003/4 (including broadcasting) is given as R2.2b (Creative Industries Report 2008:21). The fastest growing sectors over the six year period from $1997-2003$ were film and commercial servicing (200\%), video rental (148\%), and TV program production (100\%). While the film and television industry in South Africa does create jobs, $37 \%$ of which were found to be in the high and medium skilled category, the Report (2008:22) acknowledges that employment in the industry is mostly project-based, that is, consists of short-term contracts with freelance employees. Inevitably, the extent of positive outcomes from such incentive schemes are somewhat constrained by the short-term contract nature of employment in the industry, and Neff (2012) highlights one of the long-standing critiques of 
creative industries policy approaches and much academic discourse (for example, see the overview of the labour debates within Chapter 4 of Flew 2012) that they either neglect, or at least underplay, consideration of the presence and ramifications of the precarious nature of this employment (i.e. the lifestyle and career limitations arising from continuing membership of the 'precariat').

\section{b) Local versus international film production and demand in South Africa}

While the Creative Industries Report (2008:19) flags the creation of South African content as important, it acknowledges that both the local and international market for South African films and television productions is small. Botha (2003) suggests that this is a legacy of apartheid policies, which failed to take advantage of the global revival in the film industry between 1959 and 1980, neglecting audience, and distribution channel development. Instead, "Hundreds of Afrikaans soapies were made... during this time, while the world, including several African countries, explored the artistic, social and political possibilities of the medium to the fullest" (Botha 2003:183).

South African feature film production between 2000 and 2007 averaged only 7 films per year, although the trend is a rising one (NFVF 2008). The small local market is also reflected in the National Film and Video Foundation Box Office Report for 2011, which shows that South African films captured only $5 \%$ of the local market in this year, the rest going to foreign films. Of the South African films, three Afrikaans-language films, which have limited potential for international release, earned nearly half the box office revenue (NFVF 2011). Of the 47 South African films released between 2000 and 2007, most did not earn enough at the local box office to recoup even $50 \%$ of their production costs, but the minority that are released internationally did considerably better (NFVF 2008). 
Barnard and Tuomi (2009) pose the question of why the Nigerian film industry ("Nollywood") has been so much more successful in producing and selling films to Nigerian audiences than the far more technologically advanced local film industry in South Africa. Barnard and Tuomi (2009) argue that South African audiences have been exposed for longer to more sophisticated and technically advanced international films, especially from Hollywood. There is thus a gap between the sophistication of audience taste, and the (mostly) much less well developed supply-side capabilities of the South African film industry. Demand for locally produced films has thus not developed. In Nigeria, international films were less easily available, which stimulated the demand for locally produced "Nollywood" products, despite their lower quality. This stimulated Nigerian film production across a much broader range of film production activities. In contrast, access to Hollywood films in South Africa has relegated the South African film industry to being what Bernard and Tuomi (2009:653) describe as "a producer of niche services to Hollywood". In this sort of scenario, they argue that international business does result in the upgrading of capabilities, but it is likely to occur "only in pockets" (2009:661).

\section{c) The development of the new incentive schemes}

In 2004 the South African Department of Trade and Industry (DTI) introduced the "Film and Television Production Rebate Programme", with the main aim being to attract large budget foreign films to facilitate foreign capital inflow and skills transfer. Although the programme was judged to be a success (NFVF 2010), it was amended in 2008 to include support for the local film and television industry (The South African Film and Television Production and Co-production incentive) as well as foreign films (Foreign Film and Television Production incentive) (DTI 2008a; 2008b). 
Foreign productions have no requirements relating to South African ownership (including copyright) or artistic inputs. However, if they wish to apply for the DTI subsidy, they still need to comply with certain broad-based black economic empowerment rules (further explained below). As such, foreign productions would typically employ a South African film company to "service" the production, which would include advising them on requirements for subsidy eligibility, sourcing local services, applying for the subsidy, and providing the necessary information to the DTI (DTI 2012). South African productions are defined as those where the majority of intellectual capital is owned by South Africans, and where the majority of those filling key creative (head writer, director, producer) and performance (top five actors) positions. For co-productions, South Africans must be the majority shareholders, and at least one South African must play an active role in the production (DTI 2011).

A major change from the 2004 scheme was that South African productions were offered the option of receiving the subsidy as various production "milestones" (in the case of films) or episodes (in the case of television) were completed, rather than in a once-off payment when the whole project was complete (NFVF 2010). Both incentive schemes were revised again in 2011/2 in response to feedback from the industry (DTI 2011; DTI 2012); major changes being the inclusion of post-production ${ }^{1}$ activities in the incentive scheme for foreign productions and the removal of a R10m subsidy cap.

An interesting feature of the DTI incentive schemes is that, although they set some limits on the content categories that can be included (for example, the subsidy does not apply to reality $\mathrm{TV}$, discussion programmes, current affairs, advertising or commercials, amongst others),

\footnotetext{
${ }^{1}$ QSAPPE (Qualifying South African Post-Production Expenditure) was included in the 2011 incentive scheme with the intention of encouraging location-seeking foreign productions to spend more time (and money) in South Africa on follow-up post-production activities.
} 
incentive eligibility does not depend on the quality or specific topic of the proposed project. Instead, the stated aims of the incentives are (i) to attract big budget production and postproduction film and television projects, seen as a form of foreign direct investment in the case of foreign and co-production incentives; (ii) to stimulate the industry, encouraging job creation and skills transfer; and (iii) the "enhancement of the international profile" of the South African film and television sector (DTI 2012). Appendix Table A1 summarizes the main features of the current DTI incentive schemes.

However, the National Film and Video Foundation (NFVF), an agency of the Department of Arts and Culture, has a greater concern with promoting South African content and the transformation of the industry to include black South Africans, who were previously excluded from many opportunities under apartheid (Tuomi 2007). The NFVF states that, "it is a moral imperative to create facilities for ordinary South Africans to bear influence in the expression of their own image, thereby deepening democracy and creating prosperity" (NFVF website, 2012). This accords well with the objectives of the founding of the NFVF, which included "enabling South African audiences to see their own stories and interpretations of experience reflected on local screens" (Botha 2003:187).

An important goal of the South African government is the transformation of the ownership and employment profile of South African firms to represent more closely the demography of the country, with particular emphasis on the promotion of black people and, to a lesser extent, women (B-BBEE Act 2003)². Compliance with Broad-based Black Economic Empowerment

\footnotetext{
2 The B-BBEE (Broad-based Black Economic Empowerment) act of 2003 requires that South African enterprises play their part in transformation, which includes: increasing black ownership, management and control of productive assets, human resource and skills development of black people, preferential procurement of goods and services from B-BBEE enterprises and investment in enterprises that are owned and managed by
} 
(B-BBEE) objectives and reporting according to the B-BBEE scorecard (Codes of Good Practice on B-BBEE 2007) are a requirement for DTI subsidy eligibility. The scorecard consists of seven elements, with weightings (or points) attached to each. For example, ownership scores a maximum of 20 points out of 100, employment equity, 15 points and skills development, 15 points. A minimum number of points, and, for Co-productions and South African incentives, the employment of a certain percentage of South Africans in key positions, are subsidy eligibility requirements. However, micro-enterprises (defined as those with total revenue of R5 million or less per year) or start-up enterprises (in their first year) are automatically granted a B-BBEE score of a level four contributor (that is, a score of between 65 and 74), while small enterprises (defined as those with total revenue of between R5m and R35m per year) may choose any four of the seven elements on the B-BBEE scorecard on which to report.

Yet transformation in the industry has been slow. A report on South African feature film development from 2000 to 2007 (NFVF 2008) found that, of the 55 films produced in this period, only 11 were directed by black people; of the top ten grossing films during the period, only one had a black director.

The aim of this study is to analyse the effectiveness of the current incentive scheme in terms of the broader aim of transformation in South Africa and its explicitly stated objectives of (i) creating jobs, (ii) developing skills and the technological knowledge base and (iii) attracting foreign exchange. The primary source of data is information obtained from the DTI on film and television subsidies granted between 2009 and 2012. The data is used to construct a

black people (Government Gazette, 2004). South African enterprises are required to report on B-BBEE using a scorecard as set out in the Codes of Good Practice on Black Economic Empowerment (2007). 
subsidy concentration index, showing the distribution of subsidy allocation across firms in the industry over the research period. It is also used to show the trend in incentive payments over time between South African productions, co-productions between South African and foreign producers, and foreign productions; the ratio of production spending to subsidy received; the estimated contribution to real GDP; and employment by job type and race group for each category. The quantitative analysis is supplemented by qualitative data from a small number of semi-structured interviews with industry stakeholders, and unpublished industry reports to the DTI.

\section{DATA AND MODE OF ANALYSIS}

This study adopted a mixed methodological approach, weaving together empirical scrutiny of incentive claim data, review of unpublished internal industry-level reports and supplemented by a small number of elite interviews with key stakeholders in the Western Cape South African film and television sector. Data from multiple sources could thus be triangulated to support the process of cross-referencing. In this way, the credibility and reliability of findings may be increased (Tansey 2009).

The quantitative phase comprised the disaggregation and decomposition of authorized subsidy claim data provided by the South African Department of Trade and Industry (DTI) for the period 2009 to June 2012. Permission was granted to analyze only data from completed projects and no identification of individual project costs or production companies was permitted, as this might afford contemporary commercial intelligence to competing firms. The data set contained information on the date of application approval, the Qualifying South African Production Expenditure (QSAPE), and employment in various categories, divided into white and black people. QSAPE refers to production expenditure by the applicant on goods, facilities and services provided by South African companies, which could 
also include copyrights. Non-qualifying expenditures include items such as financing expenditure, general business overheads and physical capital (such as land and buildings, depreciation and the cost of services embodied in goods).

Interview participants were chosen to represent i) one of the largest production companies, focusing mainly on big-budget co-productions and foreign productions of mostly feature films (referred to as Firm A); (ii) a smaller firm, primarily involved in the production of television series and animations, with most work being South African and co-production projects; and (iii) the director of the Cape Film Commission. Interviews were conducted face-to-face, using a semi-structured format. Permission to record the interviews was granted in all cases and these recordings have been stored for subsequent checking and research access. Transcriptions of the interviews were subsequently sent to participants for checking and clarification.

In the quantitative phase the focus was the analysis of three full years of 2009-2011 of authorized incentive claims for 106 film and television projects over this period. The financial data was deflated using the South African Consumer Price Index $(2008=100)$. The distribution of the subsidy payments to firms in the industry was considered via calculation of a 'subsidy concentration index', expressing the combined subsidy (as a percentage of the total) for the top three, five and ten production companies in each year and on average over the three year period. The series of exchange rate movements (US dollar, Euro and Pound against the South African Rand) were based on data obtained from the South African Reserve Bank. Average sectoral GDP multipliers for the South African economy were obtained from the Industrial Development Corporation, a governmental development finance institution, operating under the supervision of the Economic Development ministry of South Africa. The 
relevant sectoral multipliers were then applied to give some indication of the economic and employment impact of subsidized films.

The project employment data was weighted to convert project jobs in various employment categories (producers, "creatives", crew, cast and extras) to annual Full-Time Equivalent (FTE) jobs. These weights were informed by the conducted interviews, internal industry sourced publications, and project approval and claim dates.

\section{KEY FINDINGS AND IMPLICATIONS}

\section{(a) Subsidy impact on GDP and industry competitiveness}

The most striking finding from the interviews with elite stakeholders is the contradictory views on the effectiveness of the film incentive scheme held by different role-players. Firm A (the large company, focusing mainly on big budget co-productions and servicing foreign productions) has developed considerable in-house expertise in applying for the incentives (and are highly successful in these applications), and in managing large, international projects. Their managing director commends the DTI on the clarity and simplicity of the incentive scheme, as well as their responsiveness to feedback from industry (in which Firm A has played a part), which has led to a number of changes in the schemes (as described in Appendix Table A1). Although mindful of their own stakeholder interests, the Firm A managing director points out that the competitiveness of the South African film industry depends on "the whole package", the DTI incentives have played an important part in making South Africa an attractive filming destination, and it is fully expected that the new postproduction incentives will also be successful (Firm A, Pers. Comm. 2012).

Firm B (smaller, and mostly involved in the production of South African and co-production projects relating to television series and animation) argues that the DTI film incentives are "only working for the big budget film productions, and it [accessing the incentives] is 
becoming increasingly onerous and complicated ... The reality is that two or three large service companies are going to continue to dominate the bulk of the money" (Firm B, Pers. Comm. 2012). The latter point is certainly observable from Table 1, which shows the subsidy concentration index from 2009 to 2011. Despite the fact that, in some years, smaller companies may land one large project, thus making subsidy patterns highly variable and unstable from year to year, it is clear that, on average, about half the total subsidy money goes to the top 3 firms, with nearly three-quarters going to the top 10 firms. This points to the presence of a competitive fringe, mostly representing smaller, South African projects, which may have significantly different requirements from the big foreign productions. For example, directors of both Firms A and B commented on the difficulty experienced by documentary producers in reaching the required R2.5 million minimum QSAPE needed in order to qualify for the incentives.

(Table 1 here)

For smaller firms often without in-house expertise for subsidy application and subsequent auditing requirements, a solution may be to employ someone who already has these skills. Although difficult to confirm, three separate film industry sources described significant rentseeking behaviour by such intermediaries, some of whom demanded as much as $20 \%$ of the rebate as the consulting fee. They also acknowledged that having the subsidy based on qualifying expenditure might provide an incentive for producers to inflate their budgets in order to increase the subsidy amount given.

According to the director of Firm B, the incentive scheme is biased against longer-term projects, such as the production of television series and animations. Despite the fact that these sorts of productions have the potential to provide more stable employment and training opportunities, the way the subsidies currently work makes it difficult to reinvest in the 
industry. For example, to apply for the incentives, each film or television project requires a Special Purposes Vehicle (SPV), which is a legal financial entity created for the specific project that lasts only for its duration. The DTI incentives do not allow for the purchase of equipment, but require it to be hired from a separate company (the SPV cannot own any assets). While this might be appropriate for shorter-duration projects, the Firm B director argues that it prevents firms from accumulating capital which could be used to increase their productive capacity (Firm B, Pers. Comm. 2012).

Similarly, the Firm B director argues that the new post-production incentives are "fatally flawed" in that they continue to focus on the supply side of the industry, and need to be broadened to include the demand side, such as sales, distribution, broadcast and exhibition, (the creative and ownership aspects). "We are still production - we are basically builders, not architects, we are essentially project managers - we are not part of the story here" (Pers. Comm. 2012). As argued by Bernard and Tuomi (2009), the process of learning-by-doing that characterized the film industry in Nigeria, where there was very limited foreign contact, is likely to lead to a much more incremental, broad-based upgrading of skills and capabilities across the value chain. Exposure to international competition and foreign producers in South Africa has led to the rapid development of narrowly focused niche areas to a very high level, but also to the "increasing fragmentation of the supply chain" (Bernard and Tuomi 2009: $662)$.

The Cape Film Commission (CFC), and (to a more limited extent), the 2012 Industry Report to the DTI, also make the point that the incentives might usefully be broadened to include reality shows, games, and other media forms. The Cape Film Commission director estimated that about $50 \%$ of film and television projects do not qualify for the DTI incentives, and that a Cape Film Commission study including these unsubsidized projects showed that the 
economic impact of the film industry in the Western Cape was over R5 billion in 2011/12 (CFC, Pers. Comm. 2012).

All interviewees acknowledged to varying degrees that the DTI incentives have helped in attracting larger budget foreign films and co-productions. Table 2 shows that incentive payments for South African productions and co-productions have been rising steadily (in real terms) over the study period $(2009$ - 2011), but that payments to foreign productions experienced a sharp decline in 2010. This may have been the result of the reduction in the number of international film projects (as a consequence of the global financial crisis), and the introduction of "highly competitive incentives to attract the remaining film dollars" in other countries (Industry Report 2009).

One question is the economic returns from the incentives. A way to measure this is to consider spending (QSAPE) per Rand of subsidy. The best returns from the incentives, over the three year period, are provided by foreign films (a ratio of 1:6.65), then by South African productions (1:5.36), followed by co-productions (1:3.98). This supports the claim made in the 2012 Industry Report to the DTI that foreign film subsidies, in particular, are providing a good return in terms of spending generated per subsidy Rand.

The Industrial Development Corporation (IDC) multiplier for the "Motion picture, ratio, television and other entertainment activities" sector was used to estimate the total increase in GDP per one million Rand increase in final demand. Table 2 shows that, on average, subsidized films contribute around R2.2 billion to the South African economy annually (in 2010 prices $)^{3}$.

\footnotetext{
${ }^{3}$ In terms of economic impact, film production can be understood to represent final demand in the sense that, especially for foreign and co-productions, films are not primarily consumed by South African audiences
} 
(Table 2 here)

A recurring theme in the interviews was the urgent need for the development of business skills amongst producers, especially the design of business plans that are better able to manage risk. For example, the exchange rate can be an important determinant of competitiveness for foreign and co-production projects, yet, to our knowledge, no South African production companies have invested in forward exchange rate cover. This is despite the fact that the Rand is prone to considerable volatility especially against the US Dollar, and that an industry task team, which presented a report to the DTI on the impact of the global financial crisis on foreign films made in SA (2009), specifically highlighted exchange rate volatility as a threat to the industry: "The Rand has strengthened significantly in recent months, making South African production costs up to 30\% higher in Dollar terms than a year ago" (Industry Report 2009).

What emerges from this analysis is that there is a clear divide in the industry: A relatively small number of larger firms have developed considerable expertise in attracting big foreign and co-productions, and in successfully applying for a large share of the total incentives (shown by the subsidy concentration index). The incentives, as part of an overall "package" (including good filming locations and a, albeit narrow, range of technical expertise) have helped to make South Africa a competitive filming location. Big foreign productions provide the best return in terms of spending generated per subsidy Rand. On the other hand, smaller firms producing mainly local shows, with some co-production, and focusing on forms other than feature films (such as documentary, animations and television series), manage to capture

(Creative Industries Report, 2008). In this sense, the film is the final product of the industry, and the multipliers can be applied. However, it is acknowledged that they may be an overestimate, since they refer to activities lower down the value chain than final consumption by audiences. 
only a small percentage of the incentives, lack the in-house expertise needed to make and manage the applications, and often lack business skills needed to exist sustainably in a contract-based, risky industry. They are further hampered by the South African taste for more technically sophisticated Hollywood films, resulting in a very small market for local films. The following section considers the impact of the subsidy on transformation and the labour market in the South African film industry.

\section{(b) The impact of the subsidy on transformation and skills development}

In terms of the transformation of the South African film and television industry, interviewees regarded the DTI incentives as, at best, only partially successful. The managing directors of both Firms $\mathrm{A}$ and $\mathrm{B}$ attributed this to the short term contract nature of film industry employment, and the lack of government support for training initiatives. The managing director of Firm B stated that until the film industry is doing well enough to offer continuous employment, it will only be those from wealthy, mostly white, families who can afford to go

to film school, given the risk of being frequently unemployed afterwards: "We need to promote the film industry as a career, and we have failed dismally in this area" (Firm B, Pers. Comm. 2012). In the wider global context of labour debates in the creative industries (Neff 2012, Flew 2012), this seems to align broadly with many other country experiences.

The Firm A director was more positive about B-BBEE initiatives. The requirements, particularly for co-productions (to qualify for subsidy), have been effective in getting black South Africans involved in writing, directing, and editing as well as giving South African actors an opportunity in the international market which they would not otherwise have had. However, this same director points out that, especially for feature films, which have a relatively short filming duration, the B-BBEE ownership requirements do not make sense and encourage "fronting". Since the SPVs established for each film last only as long as the 
project, designated "owners" of the SPV do not imply longer-term empowerment or control (Firm A, Pers. Comm. 2012).

The director of the Cape Film Commission (CFC) argues that transformation is happening in the film and television industry, but not because of the subsidies. Instead, he suggests that new opportunities are being created for emerging black film makers from rural communities and the townships though the establishment of new firms and cooperatives, some of which are able to access DTI funding for training, internships and creating business opportunities: "So essentially transformation is happening outside of the established film industry". Such small-scale initiatives are leading to the establishment of a number of new microenterprises and act as important sites for skills development, which is urgently needed to refresh the crew base of the mainstream film industry. Many of them fail, however, because of a lack of business skills relating to management, marketing and distribution of their products.

(Table 3 here)

Table 3 shows direct and indirect employment for film and television projects that received subsidy between 2009 and 2011 by production type. To convert raw data to comparable full time equivalent (FTE) posts, weightings were applied in order to reflect the fact that employment in the industry is mostly based on short-term contracts which run for the duration of the project. According to the Firm B respondent, feature film contracts in South Africa may last for between 6 to 10 weeks, while television series or animation projects may last for 12 to 18 months (Firm B, Pers. Comm. 2012). It also makes sense to weight different employment categories differently. For example, creative input is more likely to be employed for longer periods on either side of the actual filming (weighted as 1 year FTE employment), while extras are likely to have much shorter contracts (weighted as 3 months FTE employment). While it is acknowledged that the weightings represent very broad averages 
which are unlikely to apply equally to all projects, having no weightings (thus implicitly assuming that all employment categories represent full time equivalent employment) would result in significant overstatement of FTE employment.

Table 3 tells an interesting story in terms of the impact of subsidized film and television projects between 2009 and 2011. As expected, the percentage of black people employed in ownership (SPV) and creative categories was comparatively low for all production types, but especially for co-productions (29\% average for SPVs; $22 \%$ for creatives). The best transformation profiles were achieved in South African productions, but again skewed towards lower-level employment categories, such as extras (63\% average) and cast (58\% average).

In terms of direct full time equivalent jobs created, however, co-productions are ahead, creating an average of 2417 FTE jobs per year, closely followed by Foreign productions, with South African productions creating only about half as many (1120 per year). However, as a percentage of FTEs by production type, South African productions generate a greater percentage of higher-order jobs: $8 \%$ creatives (as compared to $1.3 \%$ in foreign productions), and $6 \%$ SPVs (as compared to less than $1 \%$ in foreign productions). This, together with the larger percentage of black South Africans employed in SA productions, suggests that these smaller productions are still important in fulfilling the transformation and skills development objectives of the DTI, as well as the development of a broader-based local film production capacity (Bernard and Tuomi 2009).

On average, subsidized film and television projects employ about 5,700 people in direct, fulltime equivalent jobs per year. Using the IDC employment multiplier for the sector, it is estimated that a further 10,000 indirect full-time equivalent jobs are generated by subsidized film and television projects in the South African economy per year. These figures are not 
inconsiderable in an economy with a current (narrow) unemployment rate of $25.5 \%$ (Quarterly Labour Force Survey 2012).

Regarding South African competitiveness, the director of the Cape Film Commission, argues that South Africa has an advantage in the combination of attributes it can offer, especially in the Western Cape. In particular, the combination of very diverse natural scenery, studio facilities, and skilled technical crews with expertise in digital technologies and postproduction, means that South Africa is well placed to compete in the international film industry (CFC, Pers. Comm. 2012).

All parties agreed that training is of key importance in the industry, but is currently not incentivized due to the short-term contract nature of most employment contracts, which discourages investment in highly mobile human capital. The Cape Film Commission director pointed out that certificates from the various film schools were generally not accredited by the South African Qualification Authority (SAQA), so that graduates did not emerge with easily marketable qualifications (CFC, Pers. Comm. 2012). The Firm B director argued strongly that, despite skills development being a stated priority of the DTI, not enough funding was forthcoming in order to make it a reality, partly because many training courses are not SAQA accredited and do not have unit standards (Firm B, Pers. Comm. 2012).

It is the Sector Education and Training Authority (SETA) that is responsible for accreditation of sector-specific courses with a focus on skills based training and internships (SETA, 2013). According to Baumgardt and Lekhetho (2013) the SETAs were established as part of a quality assurance mechanism to protect students from "fly by night" private sector institutions offering highly priced, but poor quality qualifications. While this has been successful to some degree, in that accreditation is valued and sought by such institutions, they recommend that the SETA system be extensively revised. 
"Accreditation and quality assurance should not be left in the hands of the SETAs since these have faltered because of a culture of ineptitude, bureaucracy, nepotism and cronyism. The focus of SETAs should shift from employers and other favoured service providers to learners and eligible training providers with the best practice in place" (Baumgardt and Lekhetho, 2013: 430).

The Media, Information and Communication Technologies Sector Education and Training Authority (MICT SETA) has recently undergone significant restructuring. While this has included partnerships with the NFVF and other organisations to establish internships and other training programs, many of these are still in their early stages (NFVF, 2013).

The director of Firm A pointed out that it is difficult to develop and keep skilled staff because is a "freelance industry". Trainees "still need to eat," even when the parent company is not filming. As a result, training schemes linked to specific projects are not an attractive prospect for either firms (who may invest in training staff who leave at the end of a short contract), or trainees, whose contracts, and thus skills development and salaries, are also short term.

To conclude, while subsidised film and television projects have provided direct and indirect employment, transformation and skills development in the industry have been slow. The short-term contract nature of the industry and the lack of incentive for firms to invest in highly mobile human capital make it an uncertain career path. In productions that received subsidy between 2009 and 2011, historically disadvantaged people were more often employed in lower level jobs, such as extras, than in ownership and creative categories. According to the director of the Cape Film Commission, who has clear regional and sectoral 
interests to represent and support, it is smaller, start-up enterprises that have been more successful in achieving the transformation objectives of the industry, but, he argued, they are generally hampered by poor business skills, and a lack of experience in a highly competitive market featuring volatile exchange rates.

\section{SUMMARY, POLICY IMPLICATIONS AND CONCLUDING REMARKS}

This study has demonstrated that the South African film incentive programmes may have had some areas of success in stimulating the South African film industry in several spheres, particularly in helping to attract large-budget foreign films and co-productions. For companies specializing in this area, the incentives are working well. The economic impact of subsidized films on the South African economy between 2009 and 2011 was, on average, R2.2 billion per year, with the employment of about 15,500 people in full time equivalent (direct and indirect) jobs per year. However, the opportunity cost of the public funds associated with these incentive programs has clearly not been subject to detailed scrutiny in this specific sectoral study. That said, future comparative work might usefully set these findings against investment returns from other industrial sectors or indeed returns from specific health and education programmes.

Skills development is occurring through knowledge spill-overs from foreign and coproductions, as well as various internship and training programmes. However, transformation in the industry has been slow. This is partly due to the short-term contract nature of the industry, which makes it a risky career option for emerging black film-makers, and partly due to the disincentive for private firms to invest in highly mobile human capital. The precarious nature of employment in this South African sector is seemingly mirroring other country's experiences to some degree. 
Challenges experienced by film and television producers in South Africa can be divided into general issues, experienced by all producers, and those specific to smaller-budget South African productions. General problems can be summarized as follows:

- Lack of business acumen amongst producers, especially smaller companies;

- Competition from other countries regarding incentives and subsidies;

- A sometimes volatile exchange rate;

- Lack of local demand for South African films;

- Lack of vertical integration (too narrow a focus on production)

In addition, smaller producers, and those engaged in longer term projects, experience difficulty in securing financing, for a number of reasons, including: the R2.5 million minimum spending required in order to qualify for the subsidy; rent-seeking behaviour by agents employed to help firms navigate the complexities of subsidy application and auditing requirements; and difficulties in reinvesting in the firm, since a requirement of the subsidy is that the special purpose vehicle (SPV) set up for each project cannot own any capital equipment.

An additional challenge for South African productions is the current taste preference of South African audiences for sophisticated Hollywood-produced films, which means that, unlike the Nigerian film industry, South African productions struggle to compete, even in local markets (Barnard and Tuomi 2009). Most South African productions do not cover even $50 \%$ of their costs at the box office (NFVF 2008).

Two key policy suggestions emerge. Firstly, both the Firm B director and the Cape Film Commission director suggested that using tax rebates would be more effective than the current system, especially for smaller-budget projects and those taking place over a longer time period. The rebates could be based on current reporting systems which are already a 
requirement of the South African Revenue Service. This would reduce the complexity and burden of applying for the incentives as they currently stand, and also reduce the incentive to inflate the qualifying South African production expenditure in order to maximize the subsidy. Since the film production industry is already focused largely in the Western Cape (specifically around Cape Town), a related suggestion might be the introduction of an Industrial Development Zone (IDZ), such as has been formed in other parts of South Africa, but specifically for the creative industries. That said, few state engineered IDZs have been unambiguously successful if initiated from scratch. One for the Cape Town area would, however, be more geared to enhancing support for an existing clustering. In addition to enabling the efficient administration of the proposed tax rebate system, IDZ status would also support other economic benefits such as knowledge and skills interchange, and the development of "created asset" comparative advantages to add to the current Locational advantages (Narula and Dunning 2000). Barnard and Tuomi (2009:657) point out that the Western Cape film industry, although smaller, has a great many similarities to the Toronto film cluster: "diverse knowledge bases, openness and interconnectedness between parties", which supports the idea that these advantages could be better utilized through the formal organization of a cluster or IDZ.

The second suggestion is that there is a clear need for the differentiation of the incentives to take into account the "competitive fringe" and emerging independent producers, who are currently not benefitting that much from the subsidy, as shown by the concentration index previously discussed. While it could be argued that these smaller budget productions are not as beneficial, in terms of economic impact, as the large foreign and co-production projects, they nevertheless act as valuable seedbeds for the creation and development of new talent to refresh the crew base of the industry as a whole. In addition, they are more likely to employ 
South Africans in creative and ownership positions, thus helping to achieve the black economic empowerment objectives of the South African government, and to upgrade production capabilities more widely. Until local productions can compete in terms of appeal and sophistication with Hollywood productions, they are unlikely to be able to capture a significant share of local demand.

\section{REFERENCES}

Alfaro, A., Bizuneh, G., Moore, R., Ueno, S. \& Wang, R. (2012). Microeconomics of Competitiveness: South Africa: Automotive Cluster, Harvard Business School: 1260 (PDF) [Online] Available:

http://www.isc.hbs.edu/pdf/Student_Projects/2012\%20MOC\%20Papers/MOC\%20South\%20 Africa \%20Automotive\%20Final.pdf

Austen-Smith, D. (1994). On justifying subsidies to the performing arts, Journal of Cultural Economics, 18(3) 239-249.

Barnard, H. \& Tuomi, K. (2008). How demand sophistication (de-)limits economic upgrading: Comparing the film industries of South Africa and Nigeria (Nollywood). Industry and Innovation, 15(6), 647-668.

Baumgardt, J. and Lekhetho, P. (2013). The Challenges of Quality Assurance in Private Higher Education Institutions in South Africa. Mediterranean Journal of Social Sciences, vol. 4, 3: $421-431$. 
B-BBEE Act (2003). Broad-Based Black Economic Empowerment Act. Government Gazette, Republic of South Africa, 25899, 1-9.

Bjorvatn, K. \& Eckel, C. (2006). Policy competition for foreign direct investment between asymmetric countries, European Economic Review, 50(7), 1891-1907.

Botha, M. (2003). Current film policy in South Africa: The establishment of the National Film and Video Foundation of South Africa and its role in the development of a postapartheid film industry. Communicatio: South African Journal for Communication Theory and Research, 29 (1-2), $182-198$.

CFC Pers. Comm. (2012). Personal Communication (Interview) with the Director of the Cape Film Commission, October 17, 2012. Cape Town, South Africa.

Codes of Good Practice on B-BBEE (2007). Broad-Based Black Economic Empowerment Codes of Good Practice. Government Gazette, Republic of South Africa, 29617, 1-11.

Creative Industries Report (2008). The Creative Industries in South Africa. (PDF) South African Human Sciences Research Council (HSRC), prepared for Department of Labour, South Africa. [Online] Available: https://www.labour.gov.za/downloads/documents/researchdocuments/Creative\%20Industries DoL_Report.pdf 
Cunningham, S. D. (2002). From cultural to creative industries: Theory, industry, and policy implications. Media International Australia Incorporating Culture and Policy: Quarterly Journal of Media Research and Resources (PDF) [Online] Available:

http://eprints.qut.edu.au/588/1/cunningham from.pdf

Cunningham, S.D., Ryan, M.D., Keane, M.A. \& Ordonez, D. (2008). Financing creative industries in developing countries. In: Barrowclough, D. \& Kozul-Wright, Zeljka, (eds.) Creative Industries in Developing Countries: Voice, Choice and Economic Growth. London, Routledge, pp.65-110.

De Mello Jnr, L.R. (2007). Foreign direct investment in developing countries and growth: A selective survey, Journal of Development Studies, 34(1), 1-34.

DTI (2008a). The South African Film and Television Production and Co-production Incentive. Department of Trade and Industry, Republic of South Africa (PDF) [Online] Available: http://www.thedti.gov.za/financial assistance/docs/SAco-production2008.pdf

DTI (2008b). Foreign Film and Television Production Incentive. Department of Trade and Industry, Republic of South Africa (PDF) [Online] Available:

http://www.thedti.gov.za/financial_assistance/docs/Foreign_Film_Guidelines2008.pdf 
DTI (2011). The South African Film and Television Production and Co-production Incentive. Department of Trade and Industry, Republic of South Africa (PDF) [Online] Available: http://www.thedti.gov.za/financial_assistance/docs/SAco-production.pdf

DTI (2012). Foreign Film and Television Production and Post-Production Incentive. Department of Trade and Industry, Republic of South Africa (PDF) [Online] Available:

http://www.thedti.gov.za/financial_assistance/docs/Foreign_Film_Guidelines.pdf

Evans, G. (2009). Creative Cities, Creative Spaces and Urban Policy, Urban Studies, 46 (5 and 6) $1003-1040$.

Firm A, Pers. Comm. (2012). Personal Communication (Interview) with the Managing Director of "Firm A", October 18, 2012. Cape Town, South Africa.

Firm B, Pers. Comm. (2012). Personal Communication (Interview) with the Managing Director of "Firm B", October 18, 2012. Cape Town, South Africa.

Flew. T. (2012). The Creative Industries: Culture and Policy. London, Sage Publications.

Fullerton, D. (1991). On justifications for public support of the arts, Journal of Cultural Economics, 15(2), 67-82. 
Gwee, J. (2009). Innovation and the creative industries cluster: A case study of Singapore's creative industries, Innovation: Management, Policy \& Practice, (11), 240-252.

Hall, P. (2000). Creative Cities and Economic Development, Urban Studies, 37(4), 639-649.

Hindley, B., and Smith, A. (1984). Comparative Advantage and Trade in Services, The World Economy, 7(4), 369-390.

Industry Report (2009). Report to the Department of Trade and Industry on the Impact of the Global Financial Crisis on Foreign Productions Made in South Africa. Unpublished report produced by the Joint Long Form Production Task Team of the Independent Producers Organization (IPO), The Producers Alliance (TPA), Documentary Filmmakers Association (DFA) and the South African Screen Federation (SASFED).

Industry Report (2012). Report to the Department of Trade and Industry on the Success of the Foreign Film and Television Production Incentive and South African Film and Television Production and Co-Production Incentive. Unpublished report produced by the Joint Long Form Production Task Team of the Independent Producers Organization (IPO), Documentary Filmmakers Association (DFA) and the South African Screen Federation (SASFED).

Mas-Colell, A. (1999). Should Cultural Goods Be Treated Differently? Journal of Cultural Economics, (2), 87-93. 
Narula, R \& Dunning, J. (2000). Industrial Development, Globalization and Multinational Enterprises: New Realities for Developing Countries. Oxford Development Studies, 28(2), 141-167.

Neff, G. (2012). Venture Labor: Work and the Burden of Risk in Innovative Industries, MIT Press, Cambridge, Mass, USA.

NFVF (2000). Profile of the South African Film Industry. National Film and Video Foundation (PDF) [Online] Available: http://nfvf.co.za/documents

NFVF (2008). South African Feature Films 2000 - 2007. National Film and Video Foundation (PDF) [Online] Available: http://nfvf.co.za/documents

NFVF (2010). Film and TV Production Incentive to Reward Milestones Achieved. National Film and Video Foundation (PDF) [Online] Available: www.nfvf.co.za/film-tv-productionincentive-reward-milestones-acheived

NFVF (2011). Box Office Report 2011. National Film and Video Foundation (PDF) [Online] Available: http://nfvf.co.za/document/box-office-report-2011-t3 
NFVF (2013). The NFVF and MICT Seta's partnership empowers young people. National Film and Video Foundation. [Online] Available: http://nfvf.co.za/article/the-nfvf-and-mictsetas-partnership-empowers-young-people

Nunnenkamp, P. (2004). To what extent can Foreign Direct Investment help achieve International Development Goals? The World Economy, 27(5), 657-677.

Quarterly Labour Force Survey (2012.) Quarterly Labour Force Survey, Quarter 3: 2012 Statistics South Africa. (PDF) [Online] Available:

http://www.statssa.gov.za/publications/P0211/P02113rdQuarter2012.pdf

South African Reserve Bank (2012). Online statistical query: Exchange rate data. South African Reserve Bank [Online] Available:

http://www.resbank.co.za/Research/Statistics/Pages/OnlineDownloadFacility.aspx

SAQA (2013). South African Qualifications Authority: Certificate in Film and Television Production Operations. [Online] Available:

http://regqs.saqa.org.za/viewQualification.php?id=61450

SETA (2013). Sector Education and Training Authority of South Africa. [Online] Available: http://www.seta-southafrica.com/about/

Statistics South Africa (2012). Poverty Profile of South Africa: Application of the poverty lines on the LCS 2008/2009 / Statistics South Africa (PDF) [Online] Available: http://www.statssa.gov.za/Publications/Report-03-10-03/Report-03-10-032009.pdf 
Tannenwald, R. (2010). State Film Subsidies: Not Much Bang for Too Many Bucks, Washington: Center on Budget and Policy Priorities [Online] Available:

http://www.cbpp.org/cms/index.cfm?fa=view\&id=3326

Tansey, O. (2009). Process Tracing and Elite Interviewing: A Case for Non-probability Sampling, in Methoden der vergleichenden Politik- und Sozialwissenschaft, Springer Verlag, pp 481-496.

Throsby, D. (1994). The Production and Consumption of the Arts: A View of Cultural Economics, Journal of Economic Literature, 32(1), 1-29.

Tuomi, K. (2007). Organisational shifts in the feature film industry: Implications for South Africa. Transformation, 63, 68-91.

World Bank Country Report (2012). South Africa. (PDF) [Online] Available: http://data.worldbank.org/country/south-africa\#cp wdi 
Table 1: South African Film Subsidy Concentration Index by Year

\begin{tabular}{ccccc}
\hline $\begin{array}{c}\text { Subsidy } \\
\text { Concentration } \\
\text { Index (SCI) \% } \\
\text { SCI (Top 3 }\end{array}$ & 2009 & 2010 & 2011 & $\begin{array}{c}\text { 3 Year } \\
\text { Combined }\end{array}$ \\
$\quad$ Firms) & 51.4 & 51.6 & 46.6 & 43.0 \\
$\begin{array}{c}\text { SCI (Top 5 } \\
\text { Firms) }\end{array}$ & 69.9 & 64.5 & 52.6 & 60.0 \\
$\begin{array}{c}\text { SCI (Top 10 } \\
\text { firms) }\end{array}$ & 84.4 & 80.4 & 68.5 & 73.4 \\
\hline
\end{tabular}

Source: Authors' calculations using DTI (2012)

Note: SCI determined by $\%$ share (of Top $\mathrm{N}$ firms) of total subsidy payments in each time period. 
Table 2: Incentive payments, Qualifying SA Expenditure (QSAPE) ${ }^{\mathrm{a}}$ and GDP impact from 2009 - 2011 (in millions of South African Rands ${ }^{b}$ )

\begin{tabular}{cccccccc}
\hline $\begin{array}{c}\text { Production } \\
\text { Type }\end{array}$ & $\mathbf{2 0 0 9}$ & $\mathbf{2 0 1 0}$ & $\mathbf{2 0 1 1}$ & $\begin{array}{c}\text { Incentive } \\
\text { payments } \\
\text { : 3 year } \\
\text { average }\end{array}$ & $\begin{array}{c}\text { QSAPE: 3 } \\
\text { year } \\
\text { average }\end{array}$ & $\begin{array}{c}\text { Ratio of } \\
\text { subsidy to } \\
\text { QSAPE }\end{array}$ & $\begin{array}{c}\text { Ave. } \\
\text { increase } \\
\text { in real }\end{array}$ \\
GDP p/a $^{\mathbf{d}}$
\end{tabular}

Source: Authors' calculations using DTI (2012) data

Notes:

a. Excludes 5 subsidy payments made within the budget and criteria of the pre-2008 film incentive scheme.

b. All figures reported in 2010 prices; On average, during the study period, the exchange rate varied between R6.73 (04/2011) to R10.00 (02/2009) to the US\$, with an average of R7.67

(South African Reserve Bank 2012).

c. Three year averages are used for the calculation of QSAPE because spending did not always occur in the year in which incentive payments were made, and also varies considerably from year to year, results being easily skewed by the presence of one or two large projects.

d. Nominal GDP figures were deflated using the CPI average for 2009 to the end of 2011 $(12 \%)$.

e. Sectoral multipliers from the South African Industrial Development Corporation for the film and television sector are classified under Recreational, cultural and sporting activities, including "Motion picture, radio, television and other entertainment activities", with a GDP multiplier of 2.35 (total impact for a R1 million increase in final demand in 2010 prices). 
Table 3: Average annual employment creation by subsidised films $\left(2009-2011^{\mathrm{a}}\right)$

\begin{tabular}{|c|c|c|c|c|c|c|c|c|}
\hline \multirow{2}{*}{$\begin{array}{c}\text { Production } \\
\text { type }\end{array}$} & \multicolumn{6}{|c|}{ Employment Type } & \multirow[b]{2}{*}{$\begin{array}{l}\text { Direct } \\
\text { FTE } \\
\text { jobs }\end{array}$} & \multirow[b]{2}{*}{$\begin{array}{c}\text { Indirect } \\
\text { FTE } \\
\text { jobs }^{c}\end{array}$} \\
\hline & & SPV & $\overline{\text { Crew }}$ & Cast & Creative & Extras & & \\
\hline South & Total FTE ${ }^{\mathrm{b}}$ & 71 & 260 & 221 & 85 & 483 & 1120 & 2720 \\
\hline African & $\%$ Black & $30 \%$ & $46 \%$ & $58 \%$ & $40 \%$ & $63 \%$ & & \\
\hline Co- & Total FTE & 32 & 703 & 116 & 55 & 1511 & 2417 & 3518 \\
\hline Production & $\%$ Black & $29 \%$ & $48 \%$ & $47 \%$ & $22 \%$ & $51 \%$ & & \\
\hline \multirow[t]{2}{*}{ Foreign } & Total FTE & 16 & 668 & 102 & 28 & 1349 & 2163 & 3764 \\
\hline & $\%$ Black & $32 \%$ & $45 \%$ & $40 \%$ & $43 \%$ & $68 \%$ & & \\
\hline \multirow{2}{*}{ Total } & Total FTE & 119 & 1434 & 439 & 168 & 3342 & 5700 & 10002 \\
\hline & $\%$ Black & $38 \%$ & $47 \%$ & $46 \%$ & $33 \%$ & $60 \%$ & & \\
\hline
\end{tabular}

Source: Authors' calculations using DTI (2012) data

Notes

a. 2011 projects were weighted by 1.5 to reflect the fact that raw data of films approved for subsidy in late 2011, may only have made claims in the latter half 2012. The raw data provided was only for the first half of 2012.

b. Employment duration weightings were applied to convert project jobs for each film/television project into 1 year full time equivalent (FTE) employment. The weights were:

SPV (Special Purpose vehicle): 1.0; Creative: 1.0; Cast: 0.5; Crew: 0.5; Extras: 0.25

c. Using the South African Industrial Development Corporation (2010) employment multiplier for the "Motion picture, radio, television and other entertainment activities" of 4.49 (indicating that for every R1 million increase in final demand, 4.49 FTE jobs are created in the SA economy) may be an overestimation, since it is meant to apply to final demand (presumably, consumption of "Motion picture, radio, television and other entertainment activities"). Industry reports (Industry report to the DTI, 2012) have used a multiplier of 2.5 which would result in a slightly larger impact (13 750 indirect jobs created, as opposed to 10 000 using IDC figures), and the more conservative IDC figure is thus used. 
Appendix Table A1: Features of the South African Film and Television Incentive Schemes

\begin{tabular}{|c|c|c|}
\hline & $\begin{array}{c}\text { Foreign Film and Television } \\
\text { Production and Post-Production } \\
\text { Incentive }\end{array}$ & $\begin{array}{c}\text { SA Film \& TV Production and Co- } \\
\text { production Incentives }\end{array}$ \\
\hline Objectives & $\begin{array}{l}\text { To attract large budget film and TV } \\
\text { productions and post-production } \\
\text { work that will enhance job creation, } \\
\text { skills and international profile of SA } \\
\text { film industry. }\end{array}$ & $\begin{array}{l}\text { To support the local film industry and } \\
\text { to create employment in South Africa. }\end{array}$ \\
\hline Benefits & $\begin{array}{l}20 \% \text { of QSAPE }{ }^{\mathrm{a}} \text { (no cap) QSAPE + } \\
\text { QSAPPE }{ }^{\mathrm{b}} \text { subsidy of } 22.5 \% \text { to } 25 \% \\
(2.5 \% \text { to } 5 \% \text { increase to encourage } \\
\text { post-production) }\end{array}$ & $\begin{array}{l}35 \% \text { of first R6m of QSAPE, and } \\
\text { R25\% of QSAPE thereafter (no cap). }\end{array}$ \\
\hline $\begin{array}{c}\text { Eligible } \\
\text { Applicants }\end{array}$ & $\begin{array}{l}\text { 1) QSAPE of R } 12 \mathrm{~m} \text { and above, } \\
\text { with at least } 50 \% \text { of principal } \\
\text { photography in South Africa, } \\
\text { with a } 4 \text { week minimum. } \\
\text { 2) QSAPPE of R } 1.5 \mathrm{~m} \text { and } \\
\text { above, minimum of } 2 \text { weeks. } \\
\text { 3) Applicant must be a SPV } \\
\text { 4) Compliance with B-BBEE }\end{array}$ & $\begin{array}{l}\text { 1) Applicant must be an SPV, the } \\
\text { parent company of which must } \\
\text { have a majority of South } \\
\text { African shareholders, of whom } \\
\text { at least one must play an active } \\
\text { role in the production. } \\
\text { 2) Minimum QSAPE of R2.5m. } \\
\text { 3) Compliance with B-BBEE. }\end{array}$ \\
\hline & $\begin{array}{r}\text { Source: DTI 2011 \& 2012 D } \\
\text { Notes: } \\
\text { a. QSAPE (Qualifying South Afri } \\
\text { b. QSAPPE (Qualifying South Africa } \\
\text { c. SPV (Special Pur } \\
\end{array}$ & $\begin{array}{l}\text { I website, } 2012 \\
\text { in Production Expenditure) } \\
\text { Post-Production Expenditure) } \\
\text { ose Vehicle) }\end{array}$ \\
\hline
\end{tabular}

